\title{
School Violence as a Cause of Non-Peaceful Coexistence in Public Secondary Schools in Nairobi, Kenya
}

\author{
Olivia A. Opere, Isabella Kamere, Violet Wawire \\ Department of Educational Foundations, Kenyatta University, Kahawa, Nairobi County, Kenya \\ Email: oliviaopere@gmail.com, opere.olivia@ku.ac.ke, imkamere@yahoo.com,wawire.violet@gmail.com
}

How to cite this paper: Opere, O.A., Kamere, I. and Wawire, V. (2019) School Violence as a Cause of Non-Peaceful Coexistence in Public Secondary Schools in Nairobi, Kenya. Open Journal of Social Sciences, 7, 130-145.

https://doi.org/10.4236/jss.2019.79010

Received: May 10, 2019

Accepted: September 16, 2019

Published: September 19, 2019

Copyright ( 2019 by author(s) and Scientific Research Publishing Inc. This work is licensed under the Creative Commons Attribution International License (CC BY 4.0).

http://creativecommons.org/licenses/by/4.0/

\begin{abstract}
Public secondary schools in Kenya have in the recent past experienced several unrests, a situation that has threatened the fabric that holds them together. For quite some time, there have been reported cases of arson attacks and other forms of school violence in public secondary schools in Kenya. The incidences of violence have resulted into injuries, loss of property and sometimes loss of lives. In spite of the tough measures meted out on the students who are found to be involved in such acts, not much has been achieved. Using data collected from a sample of 341 public secondary school students and 88 teachers drawn from a survey of 22 public secondary schools in Nairobi County, the paper has identified various forms, causes and perpetrators of violence in public secondary schools in Kenya. The paper has argued that the earlier the perpetrators, forms and causes of violence are identified and mitigated through acquisition of knowledge and skills on peace education, the more likely the risks will be eliminated to enable the learners to embrace peace values and peaceful coexistence in the community. The study found out that school violence occurs in the form of verbal abuses, physical fights, bullying, and arson attacks. It also emerged that violence occurred during meals, social events and on the way going home from school and that the main perpetrators included classmates, prefects and even teachers. Key contributing factors to school violence were competition for resources, political differences, sexual discrimination and non-tolerance to cultural diversity. The paper concluded that the more effectively the peace values are inculcated into students in public secondary schools, the better well behaved the students are likely to become; hence no or limited school unrests will be experienced.
\end{abstract}

\section{Keywords}

School Violence, Non-Peaceful Coexistence 


\section{Introduction}

Violence refers to any behaviour or situation that reflects the absence of peace and is intended to injure or kill someone or to destroy something. It could be physical or psychological. It presents a risk to peaceful coexistence in any institution and organization irrespective of the cause or form. Public secondary schools in Kenya have in the recent past been faced with several unrests, a situation that has threatened the fabric that holds them together. For quite some time, there have been numerous cases of arson attacks and other forms of school violence in public secondary schools in Kenya. These have mainly been occasioned by students and some have resulted in injuries, loss of property and sometimes loss of lives. In response, the affected learning institutions and the law enforcers in government have responded by imposing penalties of various proportions on students ranging from closures of schools, fines on students, suspension or expulsion of students from school. In some cases students have been charged at the law courts. In spite of these tough measures meted out on the students, not much has been achieved. Instead there has been a marked increase in the incidences of violence. Not only do students lose a lot of time from the interrupted learning but they also end up transiting into the society, after school, to become adults who are social misfits. Managing the violence at schools therefore is critical as it creates peaceful coexistence amongst the school community and enables the learners to resent violence.

Globally, violence in schools has been noted in various forms and intensity. In 2016, an estimated 560,000 people were killed violently. This corresponds to about 7.50 violent deaths per 100,000 population. If the current global trends persist, annual violent deaths are likely to increase from about 560,000 in 2016 to more than 610,000 by 2030 [1]. School violence has escalated to the extent that globally about 246 million learners are affected by this phenomenon [2]. According to the Youth Risk Behaviour Survey (YRBS) by Centers for Disease Control and Prevention (CDC), 24\% of students in the United States of America (USA) had been involved in a physical fight more than once within a period of one year [3]. South Africa has high rates of violence and prevention targets promoting school attachment and substance abuse treatment [4].

Many countries in Africa have been involved in war hence the need for sustainable peace. In recognition of the role education plays in attaining peace, the Association for the Development of Education in Africa (ADEA) facilitated the establishment of the Inter-Country Quality Node on Peace Education (ICQN-PE). Violence in the South African schools is prevalent and therefore the government has put in place intervention programmes. The post-apartheid education system which emphasizes the role of education in creating a more democratic and peaceful society has taken into account the need for a clear formal programme on PE [5]. In Ethiopia one of the aims of education is to nurture citizens who respect human rights, appreciate equality, justice and peace. Civic education has therefore been included in the curriculum at the secondary school level [6]. 
In Kenya, the first incidence of school violence reported was at Maseno School in 1908 [7]. There has been an upsurge of violence in public secondary schools in Kenya. In the 1990s through to the 2000s school violence has resulted into loss of lives, burning of schools and massive destruction of school property [7]. Several strategies have therefore been put in place to mitigate school violence in line with the goals. The Ministry of Education, Science and Technology (MoEST), Kenya in recognition of the fact that education provides a pedestal for promoting peaceful coexistence has therefore put into place various programmes introduced since 2008 when the teaching of Life Skills Education (LSE) was made compulsory in Kenyan public secondary schools as a remedy to various psychosocial challenges faced by learners [8]. According to a report made by the National Crime Research Centre (NCRC), in the year 2016 school violence was experienced in over 130 secondary schools within a period of two months [9]. Additionally, the media has published numerous stories on school violence.

Despite the various interventions, incidences of school violence still exist with a marked increase in cases of fights, sexual violence, corporal punishment, arson attacks and verbal abuse and others. To mitigate the problem of school violence in public secondary schools, various strategies have been employed. Earlier efforts involved constituting of commissions of inquiry and committees to investigate school unrests. These included; the presidential committee on students unrest and indiscipline in Kenya secondary schools [10]; Naomi Wangai taskforce on Student Discipline and Unrest in Secondary Schools proposed banning of all activities that were seen to promote violence among students [11] and the Parliamentary Departmental Committee formed to establish the causes of student unrest and strikes in secondary Schools [12].

The paper has identified the forms, causes and perpetrators of violence in public secondary schools in Kenya and how the prevalence of violence in public secondary schools has threatened peaceful coexistence amongst the school communities.

\section{Analytical Framework}

The paper has used Thomas Hobbes' Social Contract Theory as a basis for understanding the existence of school violence. The theory argues that human beings as natural aggressors who are innately competitive and insecure hence the need to submit to an authority who then ensures social order. Secondly, that human beings get involved in acts of violence to enhance their own security and to display power. It further postulates that social contracts are negotiated through conflicts which portray the balancing of capabilities and personal interests and powers among people and therefore violent behaviour is a manifestation of such forces. In the context of the paper, it is argued that students are in constant competition for resources, positions or response to societal conflicts whose pursuits result in conflicts thereby leading to school unrests in terms of personal interests and capabilities. The school management presents a manifestation of authority through school policies and rules which regulate the behaviour of stu- 
dents through the inculcation of peace values such as mutual respect and cooperation. Mutual adjustments to tolerating each other will lead to harmonious coexistence. The failure of the enforcement of the authority to manage the conflicts therefore leads to conflicts amongst the students hence school unrests. The competitive desire for increased security as resulting in an ever increasing feeling of insecurity. He is convinced that if human beings are assured of security, they are likely to be at peace with one another but left to themselves human beings are bound to engage in endless conflict. These views were considered in establishing whether competition among students is a major cause of violence and to reiterate the need for the secondary school curriculum to emphasize acquisition of values such as cooperation, teamwork, empathy, mutual respect, harmony and tolerance. Hobbes' ideas were also useful in establishing if the perpetrators of violence in schools are innately bound to practice such vices and the extent to which peace values acquired in school can transform them into embracing peaceful coexistence.

The prevalence of school violence in Kenya is premised on the fact that the perpetrators of violence are selfish in their pursuit of gratification, leadership and acquisition of resources within their socio-economic and political environments, hence lack of peaceful coexistence in schools. Incidences of school property vandalism, fights and emotional perpetrations, discriminations and social isolations, blackmails, threats, insults, ridicules, exclusions results in violence in schools. The school authorities facilitate avoidance of school violence by way of embracing non-violent ways of solving controversial issues, and maintaining mutual respect for one another. It presupposes an obligation to refrain from any form of violence but instead ensures there exists, harmony and cooperation among learners from diverse environment, socio-cultural and political backgrounds. Each one of them may hold different opinions and perceptions towards certain issues like distribution of resources, political orientation and leadership inclinations with the disadvantaged blaming their status to that of their tormentors or the advantaged while the latter ensures the sustenance of the status quo. The inability to reconcile these various views may give rise to school violence such as physical confrontations, religious, ethnic and gender discrimination and verbal abuse. In view of Hobbes' ideas, the violent tendencies can be controlled when the authority in the person of teachers, school administration, and the government take charge through the school curriculum and leadership and governance guidance. In the context of education, Harber and Sakade (2009) observed that schools are prone to violence due to the high authoritarianism by teachers and head teachers hence resulting into less democratic environment occasioned by less appreciation of human rights and critical awareness [13]. The students are therefore subjected to despotic situations in which students are violently treated and also exposed to violent beliefs arising from the dominant norms of the wider society. This appeared to have followed the view of Green, 1990 'the task of public schooling was not so much to develop new skills for the industrial sector as to inculcate habits of conformity, discipline and morality that 
would counter the widespread problems of social disorder' and that of Kelly 1986 explaining the role of the teacher during the period of enlightenment as that of imparting factual body of knowledge to immature recipients who are not expected to challenge, a scenario that led to authoritarianism. The schools therefore took the form of discipline and punishing students so as to create order in the society. It therefore attempts to challenge the social norms as passed through stages and administered in the school curriculum by the school masters that foster violence in schools.

\section{Methodology}

This study adopted a cross-sectional research design and employed a mixed method methodology. This approach involved a concurrent qualitative and quantitative approach [14]. It was administered through a survey questionnaire and Focus Group Discussions (FGDs) to determine the trends in prevalence levels of violence, among learners in public secondary schools.

The study was conducted in 10 administrative sub-counties of Nairobi County namely; Kasarani, Kibra, Westlands, Dagorretti, Langata, Kamkunji. Njiru, Embakasi, Kamkunji and Makadara. Nairobi County was selected for being cosmopolitan therefore prone to ethnic based violence. Secondly, because of the existence of areas such as Kibera and Mathare which were referred to as "hotspots" because of the frequent eruptions of violence whenever political disputes arise in Kenya. Respondents from seven (7) categories of schools, namely, Boys' Boarding (BB), Girls' Boarding (GB), Boys' Day (BD), Girls' Day (GD), Coeducational Day (CD), Coeducational Day/Boarding (CD\&B), and Boys' Boarding/Day $(B B \& D)$ were targeted. The study employed various sampling techniques. Purposive sampling was used to identify Nairobi due to its heterogeneity and the fact that it possesses all the desired characteristics and categories from a population of 63 public secondary schools.

Nairobi County consists of 27 Day Schools and 36 Boarding schools. Stratified sampling technique was used to identify public secondary schools based on the seven (7) categories From each stratum, the secondary schools were further stratified into boys' only and girls "only schools taking into consideration the fact that there is only one girls" day and one Coeducational "boarding and boys" day public secondary schools in this County. From each of the seven (7) categories, the strata/substrata was identified as follows; Boys Boarding (5): Dagoretti High, Langata High, Ofafa Jericho High, Muhuri Muchiri High, Highway, Girls Boarding: (5) Kariobangi, North Girls' Day school, St Teresa Girls', Pangani Girls', St Annes Girls', Parklands: Boys Day (2) Ruai, St Teresa, Girls Boarding (1) Huruma Girls': Mixed Day (7) Ushirika Mixed, Embakasi Garrison, Mbagathi Sec, Peter Kibukosya, Ruthimitu, Mwangaza, Shadrack Kimalel, Mixed day/boarding (1)—Maina Wanjigi, Boys Boarding/day (1), Jamhuri High school. The stratification process took into consideration the diversities in gender and categories of school.

This technique accorded every student in the sample an equal chance of being 
selected as a participant. Thereafter respondents were sampled from each of the identified schools. The required 30\% percent from each cluster were randomly picked from the containers to obtain a total number of 22 secondary schools. The process ensured there was no bias as far as the selection of the schools was concerned.

The total number of students in the public secondary schools within Nairobi County was 69,934. The sample size was determined using Krejcie-Morgan-sample-size-table which was developed by Krejcie and Morgan at confidence level of 95 per cent and a margin of error of 5 per cent is 384 [15]. From each of the 22 schools, an average of 19 respondents (teachers and students) were sampled giving a total sample size of 426 respondents. Based on the teacher student ratio $20 \%$ (85) of the teachers and 341 students were interviewed. An average of four teachers per school were identified based on their role in implementing peace education programmes in the school. The students were randomly selected from all the class levels and positions of responsibility in the school including class teachers, heads of department, club leaders, prefects and ordinary students.

The sample comprised 426 respondents consisting of 85 teachers and 341 students drawn from 22 secondary schools. The secondary schools were clustered into seven (7) categories, namely, Boys Boarding (101), Girls Boarding (90), Boys Day (65), Girls Day (21), and Mixed Day (116). Mixed Day/Boarding (14), and Boys Boarding/Day (19).

Data was coded, entered and cleaned ready for processing and analysis using descriptive statistics in Statistical Packages for Social Science (SPSS 21). Cross tabulations of the responses obtained were used to generate relevant information and to establish the general trend of findings on the various variables that were under investigation and the findings presented using percentages and tables.

\section{Data Analysis and Discussion}

In order to identify the prevalence level of violence in schools, the study hypothesized that prevalence of violence impedes the inculcation of peace values thereby resulting into undisciplined school communities. This is a situation where there is lack of peaceful coexistence in school communities. The prevalence of violence in schools was measured by identifying the presence of various indicators of violence in each category of schools. These indicators were assessed by: establishing the various forms and manifestations of violence ever observed or experienced by the respondent, when and where violence occurs, identifying the perpetrators of violence, and the causes of violence.

\subsection{Forms and Manifestations of Violence}

To avert violence in schools using effective intervention strategies, it was necessary to identify the various forms and manifestations of school violence. There were respondents who had either experienced or been victims of violence. Yet 
there were others who had only observed it at third party level. To establish those who had experienced violence, respondents were asked to state whether or not they had experienced or been victims of violence and the responses shown in Figure 1.

The participants in the study who had experienced violence in one way or the other in the last 2 years was larger than those who had not. The figure shows that 69.2 per cent of the respondents reported having either been a victim or had experienced violence while $30.8 \%$ had not. This is an indication that violence is prevalent in secondary schools and hence the need for a sustainable solution to this problem.

In order to establish the forms of violence in secondary schools in Kenya, respondents were asked to state whether or not they had witnessed, experienced or been a victim of any form of violence The responses by category of schools were cross tabulated and the results shown in Table 1.

Table 1 shows the specific nature and prevalence level of school violence witnessed or experienced by the respondents in the seven categories of public secondary schools. They could either have been in places where violence occurred, were the actual perpetrators of violence or they could have been themselves victims of violence.

It is evident from Table 1 that physical fights at $38.0 \%$ was the most prevalent form of violence followed by verbal abuse at $25.9 \%$ and bullying at $15.0 \%$. It was further observed that killings and arson attacks are the least forms violence at $0.6 \%$. This is consistent with data from a study which shows that Uganda is one of the world's highest with $36 \%$ of 13 - 15-year-olds having been involved in a physical fight and 54\% of 15 - 19-year-olds having experienced physical violence since age 15 years [16]. Notably, only $2.3 \%$ of all respondents have never in any way been involved in any form of violence during the same period. When considered in terms of category of schools it was established that school violence is more prevalent in mixed day schools at $27.7 \%$ followed by boys' boarding schools and girls' boarding schools at $21.1 \%$ each. This is in comparison to girls' day schools at $5.9 \%$ and boys' day's schools at $14.3 \%$. It also emerged that sexual violence, though minimal, is only prevalent in boarding schools, girls boarding at $1.2 \%$ and boys boarding and boys day at $0.3 \%$ each. The most prevalent form of violence in girls' schools is verbal abuse at $7.5 \%$ followed by fights at $6.2 \%$ while the most prevalent form of violence in Coeducational day schools and boys' boarding schools are physical fights followed by bullying in that order. It was further established that violence is least prevalent in boys 'only day schools. This is consistent with the findings of a study by Ndetei et al. which indicated that between $63.2 \%$ (640) and $81.8 \%$ (828) of students have been involved in various forms of bullying, with notable gender, age and class level variations [17]. This is further corroborated by the findings of Ngesu on the prevalence rate of fighting among students which was at $37.5 \%$ while cases of assaulting teachers was at $8.3 \%$, drug taking at $25 \%$, boycotting classes at $20.9 \%$ and arson attacks at $8.3 \%[18]$. 
Have you observed/experienced/been a victim of any form of violence in the last one year

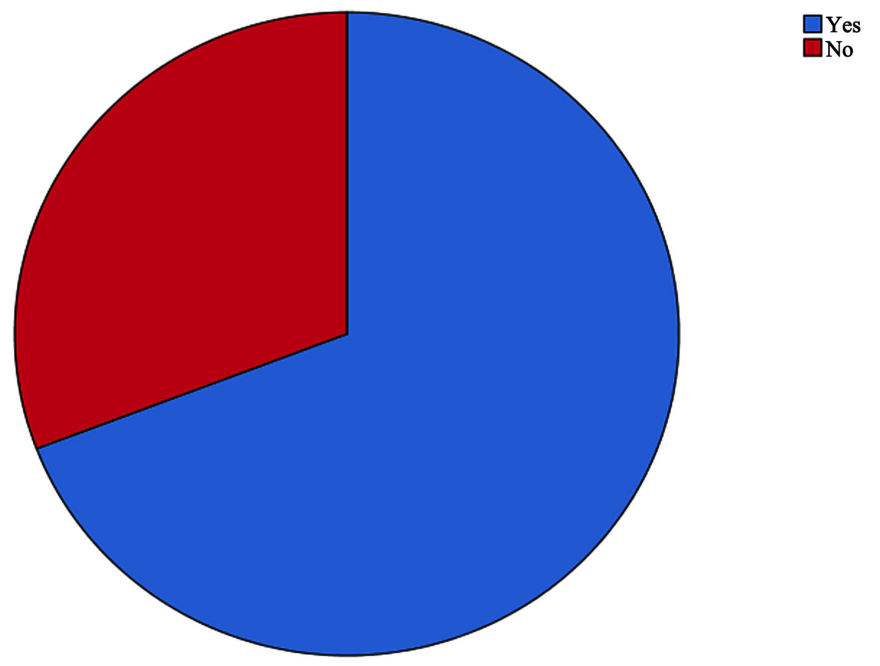

Figure 1. Showing the distribution of those who have experienced or witnessed violence in schools.

Table 1. Forms of violence observed/ witnessed in the last 2 years by category of schools.

\begin{tabular}{|c|c|c|c|c|c|c|c|c|}
\hline \multirow[b]{2}{*}{ Types of Violence } & \multicolumn{7}{|c|}{ Category of School } & \multirow[b]{2}{*}{ Total } \\
\hline & $\begin{array}{l}\text { Boys } \\
\text { Boarding }\end{array}$ & $\begin{array}{l}\text { Girls } \\
\text { Boarding }\end{array}$ & $\begin{array}{l}\text { Boys } \\
\text { Day }\end{array}$ & $\begin{array}{l}\text { Girls } \\
\text { Day }\end{array}$ & $\begin{array}{l}\text { Mixed } \\
\text { Day }\end{array}$ & $\begin{array}{l}\text { Mixed } \\
\text { Day \& } \\
\text { Boarding }\end{array}$ & $\begin{array}{l}\text { Boys } \\
\text { Boarding/ } \\
\text { Day }\end{array}$ & \\
\hline \multirow{2}{*}{ Bullying } & 8 & 10 & 11 & 2 & 16 & 0 & 1 & 48 \\
\hline & $2.5 \%$ & $3.1 \%$ & $3.4 \%$ & $0.6 \%$ & $5.0 \%$ & $0.0 \%$ & $0.3 \%$ & $15.0 \%$ \\
\hline \multirow{2}{*}{$\begin{array}{l}\text { Corporal } \\
\text { Punishment }\end{array}$} & 6 & 3 & 7 & 2 & 4 & 0 & 1 & 23 \\
\hline & $1.9 \%$ & $0.9 \%$ & $2.2 \%$ & $0.6 \%$ & $1.2 \%$ & $0.0 \%$ & $0.3 \%$ & $7.2 \%$ \\
\hline \multirow{2}{*}{ Verbal Abuse } & 14 & 24 & 13 & 5 & 25 & 1 & 1 & 83 \\
\hline & $4.4 \%$ & $7.5 \%$ & $4.0 \%$ & $1.6 \%$ & $7.8 \%$ & $0.3 \%$ & $0.3 \%$ & $25.9 \%$ \\
\hline \multirow{2}{*}{ Fights } & 33 & 20 & 11 & 7 & 36 & 5 & 10 & 122 \\
\hline & $10.3 \%$ & $6.2 \%$ & $3.4 \%$ & $2.2 \%$ & $11.2 \%$ & $1.6 \%$ & $3.1 \%$ & $38.0 \%$ \\
\hline \multirow{2}{*}{ Discrimination } & 4 & 8 & 1 & 1 & 5 & 1 & 2 & 22 \\
\hline & $1.2 \%$ & $2.5 \%$ & $0.3 \%$ & $0.3 \%$ & $1.6 \%$ & $0.3 \%$ & $0.6 \%$ & $6.9 \%$ \\
\hline \multirow{2}{*}{ Sexual violence } & 1 & 4 & 1 & 0 & 3 & 0 & 0 & 9 \\
\hline & $0.3 \%$ & $1.2 \%$ & $0.3 \%$ & $0.0 \%$ & $0.9 \%$ & $0.0 \%$ & $0.0 \%$ & $2.8 \%$ \\
\hline \multirow{2}{*}{ Killings } & 1 & 0 & 0 & 1 & 0 & 0 & 0 & 2 \\
\hline & $0.3 \%$ & $0.0 \%$ & $0.0 \%$ & $0.3 \%$ & $0.0 \%$ & $0.0 \%$ & $0.0 \%$ & $0.6 \%$ \\
\hline \multirow{2}{*}{$\begin{array}{l}\text { Arson attack/Burning } \\
\text { of schools }\end{array}$} & 1 & 0 & 0 & 1 & 0 & 0 & 0 & 2 \\
\hline & $0.3 \%$ & $0.0 \%$ & $0.0 \%$ & $0.3 \%$ & $0.0 \%$ & $0.0 \%$ & $0.0 \%$ & $0.6 \%$ \\
\hline \multirow{2}{*}{ None } & 3 & 2 & 2 & 0 & 0 & 2 & 1 & 10 \\
\hline & $0.9 \%$ & $0.6 \%$ & $0.6 \%$ & $0.0 \%$ & $0.0 \%$ & $0.6 \%$ & $0.3 \%$ & $3.1 \%$ \\
\hline \multirow{2}{*}{ Total } & 71 & 71 & 46 & 19 & 89 & 9 & 16 & 321 \\
\hline & $22.1 \%$ & $22.1 \%$ & $14.3 \%$ & $5.9 \%$ & $27.7 \%$ & $2.8 \%$ & $5.0 \%$ & $100.0 \%$ \\
\hline
\end{tabular}


It was concluded that school violence is more prevalent in co-educational day schools. This means the fights and verbal abuses are gender based and that the girls will easily insult one another whereas the boys would rather sort out their differences by fighting. The forms of violence are also consistent across the categories of schools save for the intensity of the prevalence. In all cases the peaceful co-existence in public secondary schools is therefore compromised. It was observed that either the deputy principal in some schools and in others the discipline masters or mistresses maintained a record of indiscipline cases. These records were reviewed and it emerged that in Coeducational day secondary schools out of the indiscipline cases reported boys were involved in fights more than girls and girls were reported to verbally abuse one another more.

This shows that cases of students fighting in school were prevalent and the teachers had to mediate whenever this happens. Mediation is intended to achieve a compromise on a certain issue. It requires the mediator in this case the deputy principal to first listen to the complainants, investigate to the matter and thereafter make recommendations which should be agreeable to both parties.

\subsection{Where and When Violence Does Take Place?}

In order to establish where and when violence frequently occurs in public secondary schools in Nairobi, respondents were asked to state on what occasions and/which places violence frequently occurred. The responses by schools were cross tabulated and the results shown in Table 2.

Table 2 shows that majority of the respondents (36.4\%) indicated that violence mostly takes place during social events. A further discussion held with the respondents revealed that the social events such as sports and games which took place outside the school compound were prone to violence because the perpetrators are convinced that the school authorities would not be informed of such incidences. This means that in the absence of teachers or the school principal the students engaged in acts of violence. This confirms Thomas Hobbes' argument that human beings upon undertaking to respect each other and live in peace and harmony, allowed an authority to ensure protection of life. The school administration in this case is the symbol of authority which ensures discipline is achieved. It is no wonder therefore that the students are more prone to acts of violence while away from school. Further, The 2001 the Presidential Committee on Students' Unrest and Indiscipline in Kenyan Secondary Schools attributed the problem of indiscipline in schools to a culture of violence due to lack of guidance and counseling [19].

The social events were also avenues for competition for status or recognition, resources in form of awards which attract conflicts. Further $28.7 \%$ of the respondents indicated that violence happened during meals while $11.1 \%$ on the way home from school and $6.9 \%$ while at home due to absence of authority and implied political differences. That meant that school violence happened to a larger extent where there are points of interaction and competition. In essence, this means that the students have not internalized the peace values that could condition their peaceful coexistence even in the absence of authority. 
Table 2. Distribution of where violence frequently occurs by category of schools.

\begin{tabular}{|c|c|c|c|c|c|c|c|c|}
\hline \multirow[b]{2}{*}{$\begin{array}{l}\text { violence frequently } \\
\text { occurs }\end{array}$} & \multicolumn{7}{|c|}{ Category of School } & \multirow[b]{2}{*}{ Total } \\
\hline & $\begin{array}{l}\text { Boys } \\
\text { Boarding }\end{array}$ & $\begin{array}{l}\text { Girls } \\
\text { Boarding }\end{array}$ & $\begin{array}{l}\text { Boys } \\
\text { Day }\end{array}$ & $\begin{array}{l}\text { Girls } \\
\text { Day }\end{array}$ & $\begin{array}{l}\text { Mixed } \\
\text { Day }\end{array}$ & $\begin{array}{l}\text { Mixed } \\
\text { Day \& } \\
\text { Boarding }\end{array}$ & $\begin{array}{l}\text { Boys } \\
\text { Boarding/ } \\
\text { Day }\end{array}$ & \\
\hline \multirow{2}{*}{ During meals } & 34 & 17 & 12 & 4 & 40 & 3 & 7 & 117 \\
\hline & $8.4 \%$ & $4.2 \%$ & $2.9 \%$ & $1.0 \%$ & $9.8 \%$ & $0.7 \%$ & $1.7 \%$ & $28.7 \%$ \\
\hline \multirow{2}{*}{ During social events } & 29 & 43 & 30 & 7 & 27 & 7 & 5 & 148 \\
\hline & $7.1 \%$ & $10.6 \%$ & $7.4 \%$ & $1.7 \%$ & $6.6 \%$ & $1.7 \%$ & $1.2 \%$ & $36.4 \%$ \\
\hline \multirow{2}{*}{ During class } & 9 & 11 & 6 & 3 & 5 & 1 & 1 & 36 \\
\hline & $2.2 \%$ & $2.7 \%$ & $1.5 \%$ & $0.7 \%$ & $1.2 \%$ & $0.2 \%$ & $0.2 \%$ & $8.8 \%$ \\
\hline \multirow{2}{*}{ During games/clubs } & 3 & 1 & 3 & 0 & 7 & 0 & 1 & 15 \\
\hline & $0.7 \%$ & $0.2 \%$ & $0.7 \%$ & $0.0 \%$ & $1.7 \%$ & $0.0 \%$ & $0.2 \%$ & $3.7 \%$ \\
\hline \multirow{2}{*}{$\begin{array}{l}\text { On the way home } \\
\text { from or to school }\end{array}$} & 5 & 6 & 6 & 6 & 19 & 2 & 1 & 45 \\
\hline & $1.2 \%$ & $1.5 \%$ & $1.5 \%$ & $1.5 \%$ & $4.7 \%$ & $0.5 \%$ & $0.2 \%$ & $11.1 \%$ \\
\hline \multirow{2}{*}{ In the dormitory } & 6 & 3 & 2 & 0 & 1 & 0 & 1 & 13 \\
\hline & $1.5 \%$ & $0.7 \%$ & $0.5 \%$ & $0.0 \%$ & $0.2 \%$ & $0.0 \%$ & $0.2 \%$ & $3.2 \%$ \\
\hline \multirow{2}{*}{ At home } & 4 & 6 & 5 & 1 & 11 & 0 & 1 & 28 \\
\hline & $1.0 \%$ & $1.5 \%$ & $1.2 \%$ & $0.2 \%$ & $2.7 \%$ & $0.0 \%$ & $0.2 \%$ & $6.9 \%$ \\
\hline \multirow{2}{*}{ In the staffroom } & 2 & 1 & 1 & 0 & 1 & 0 & 0 & 5 \\
\hline & $0.5 \%$ & $0.2 \%$ & $0.2 \%$ & $0.0 \%$ & $0.2 \%$ & $0.0 \%$ & $0.0 \%$ & $1.2 \%$ \\
\hline \multirow{2}{*}{ Total } & 92 & 88 & 65 & 21 & 111 & 13 & 17 & 407 \\
\hline & $22.6 \%$ & $21.6 \%$ & $16.0 \%$ & $5.2 \%$ & $27.3 \%$ & $3.2 \%$ & $4.2 \%$ & $100.0 \%$ \\
\hline
\end{tabular}

\subsection{Perpetrators of Violence}

In a bid to find out the perpetrators of violence in public secondary schools in Nairobi, respondents were asked to state who the perpetrators were. The responses by category of schools were cross tabulated and the results shown in Table 3.

Table 3 shows that the most common perpetrators of violence are classmates at $29.6 \%$ followed by strangers at $28.5 \%$. In terms of category of schools, Coeducational day schools at $26.0 \%$ have the highest number of perpetrators followed by Boys' boarding schools and $23.7 \%$ and Girls' boarding schools at $21.6 \%$. The high number of perpetrators being reported in CD schools and by strangers further confirms the socio environmental risks associated with travelling to and from school by students. The day scholars are exposed to violence. The risks emanate from political and social undertones from parents and neighbors. From FGDs, the discussants were of the opinion that the classmates would be older than the victim and in many instances prefects or fellow students who hold leadership positions in co-curriculum activities.

To some extent teachers were also mentioned to be perpetrators of violence by way of administering corporal punishment. 
Table 3. The most common perpetrators of violence by category of schools.

\begin{tabular}{|c|c|c|c|c|c|c|c|c|}
\hline \multirow{2}{*}{$\begin{array}{l}\text { most common } \\
\text { perpetrators/ } \\
\text { committers of } \\
\text { violence }\end{array}$} & \multicolumn{7}{|c|}{ Category of School } & \multirow[b]{2}{*}{ Total } \\
\hline & $\begin{array}{l}\text { Boys } \\
\text { Boarding }\end{array}$ & $\begin{array}{l}\text { Girls } \\
\text { Boarding }\end{array}$ & $\begin{array}{l}\text { Boys } \\
\text { Day }\end{array}$ & $\begin{array}{l}\text { Girls } \\
\text { Day }\end{array}$ & $\begin{array}{l}\text { Mixed } \\
\text { Day }\end{array}$ & $\begin{array}{l}\text { Mixed } \\
\text { Day \& } \\
\text { Boarding }\end{array}$ & $\begin{array}{l}\text { Boys } \\
\text { Boarding/ } \\
\text { Day }\end{array}$ & \\
\hline \multirow{2}{*}{ None } & 5 & 7 & 3 & 2 & 4 & 2 & 0 & 23 \\
\hline & $1.3 \%$ & $1.8 \%$ & $0.8 \%$ & $0.5 \%$ & $1.0 \%$ & $0.5 \%$ & $0.0 \%$ & $5.9 \%$ \\
\hline \multirow{2}{*}{$\begin{array}{l}\text { Extended family } \\
\text { members of the } \\
\text { opposite sex }\end{array}$} & 5 & 14 & 4 & 2 & 12 & 1 & 0 & 38 \\
\hline & $1.3 \%$ & $3.6 \%$ & $1.0 \%$ & $0.5 \%$ & $3.1 \%$ & $0.3 \%$ & $0.0 \%$ & $9.8 \%$ \\
\hline \multirow{2}{*}{ Classmates } & 30 & 20 & 15 & 5 & 39 & 3 & 3 & 115 \\
\hline & $7.7 \%$ & $5.1 \%$ & $3.9 \%$ & $1.3 \%$ & $10.0 \%$ & $0.8 \%$ & $0.8 \%$ & $29.6 \%$ \\
\hline \multirow{2}{*}{ Prefects } & 10 & 7 & 3 & 0 & 3 & 0 & 2 & 25 \\
\hline & $2.6 \%$ & $1.8 \%$ & $0.8 \%$ & $0.0 \%$ & $0.8 \%$ & $0.0 \%$ & $0.5 \%$ & $6.4 \%$ \\
\hline \multirow{2}{*}{ Strangers } & 22 & 21 & 27 & 7 & 27 & 1 & 6 & 111 \\
\hline & $5.7 \%$ & $5.4 \%$ & $6.9 \%$ & $1.8 \%$ & $6.9 \%$ & $0.3 \%$ & $1.5 \%$ & $28.5 \%$ \\
\hline \multirow{2}{*}{ Teachers } & 6 & 1 & 2 & 0 & 2 & 2 & 0 & 13 \\
\hline & $1.5 \%$ & $0.3 \%$ & $0.5 \%$ & $0.0 \%$ & $0.5 \%$ & $0.5 \%$ & $0.0 \%$ & $3.3 \%$ \\
\hline \multirow{2}{*}{ Colleagues } & 12 & 8 & 7 & 1 & 10 & 2 & 3 & 43 \\
\hline & $3.1 \%$ & $2.1 \%$ & $1.8 \%$ & $.3 \%$ & $2.6 \%$ & $0.5 \%$ & $0.8 \%$ & $11.1 \%$ \\
\hline \multirow{2}{*}{ Others } & 2 & 6 & 3 & 4 & 4 & 1 & 1 & 21 \\
\hline & $0.5 \%$ & $1.5 \%$ & $0.8 \%$ & $1.0 \%$ & $1.0 \%$ & $0.3 \%$ & $0.3 \%$ & $5.4 \%$ \\
\hline \multirow{2}{*}{ Total } & 92 & 84 & 64 & 21 & 101 & 12 & 15 & 389 \\
\hline & $23.7 \%$ & $21.6 \%$ & $16.5 \%$ & $5.4 \%$ & $26.0 \%$ & $3.1 \%$ & $3.9 \%$ & $100.0 \%$ \\
\hline
\end{tabular}

One of the discussants during a FGD said:

"Hawa form fours wanatudharau sana. Wakitupata kwa line wana ruka line ama mutu Translation" "these form fours disrespect us. whenever they find us on the queue for food they they even take the food. Anachukuwa chakula hako. This is very unfair. Wanajifanya wako Wako busy sana" Translation-they pretend they are busy.

This points to the possibility that corporal punishment is still in existence in secondary schools against the policy of the government of Kenya, which had by 2015 outlawed corporal punishment in schools and provided guidelines for positive discipline in schools [20]. As observed by Likoye that school violence affects the students as well as the school administrators [21].

Table 4 shows that the most common perpetrators of violence are form fours at $30.1 \%$ followed by form twos and form two at $25.0 \%$ and form three $24.5 \%$ and least in form one at $20.2 \%$. Whereas to forms one and three, strangers at $8.7 \%$ and $8.0 \%$, respectively were the most common perpetrators of violence, to forms two and four, classmates are the highest perpetrators of violence at $10.6 \%$ and $10.9 \%$, respectively. This further confirms that there are socio environmental risks associated with travelling to and from school by students. 
Table 4. The most common perpetrators/committers of violence by classes.

\begin{tabular}{|c|c|c|c|c|c|}
\hline \multirow{2}{*}{$\begin{array}{c}\text { Most common } \\
\text { perpetrators/committers } \\
\text { of violence }\end{array}$} & \multicolumn{4}{|c|}{ Class } & \multirow{2}{*}{ Total } \\
\hline & Form 1 & Form 2 & Form 3 & Form 4 & \\
\hline \multirow[b]{2}{*}{ None } & 2 & 5 & 4 & 7 & 18 \\
\hline & $0.6 \%$ & $1.6 \%$ & $1.3 \%$ & $2.2 \%$ & $5.8 \%$ \\
\hline \multirow{2}{*}{$\begin{array}{l}\text { Extended family members } \\
\text { of the opposite sex }\end{array}$} & 6 & 11 & 3 & 7 & 27 \\
\hline & $1.9 \%$ & $3.5 \%$ & $1.0 \%$ & $2.2 \%$ & $8.7 \%$ \\
\hline \multirow{2}{*}{ Classmates } & 12 & 33 & 20 & 34 & 99 \\
\hline & $3.8 \%$ & $10.6 \%$ & $6.4 \%$ & $10.9 \%$ & $31.7 \%$ \\
\hline \multirow{2}{*}{ Prefects } & 2 & 8 & 5 & 4 & 19 \\
\hline & $0.6 \%$ & $2.6 \%$ & $1.6 \%$ & $1.3 \%$ & $6.1 \%$ \\
\hline \multirow{2}{*}{ Strangers } & 27 & 15 & 25 & 24 & 91 \\
\hline & $8.7 \%$ & $4.8 \%$ & $8.0 \%$ & $7.7 \%$ & $29.2 \%$ \\
\hline \multirow{2}{*}{ Teachers } & 2 & 0 & 7 & 3 & 12 \\
\hline & $0.6 \%$ & $0.0 \%$ & $2.2 \%$ & $1.0 \%$ & $3.8 \%$ \\
\hline \multirow{2}{*}{ Colleagues } & 6 & 5 & 11 & 13 & 35 \\
\hline & $1.9 \%$ & $1.6 \%$ & $3.5 \%$ & $4.2 \%$ & $11.2 \%$ \\
\hline \multirow{2}{*}{ Others } & 6 & 1 & 2 & 2 & 11 \\
\hline & $1.9 \%$ & $0.3 \%$ & $0.6 \%$ & $0.6 \%$ & $3.5 \%$ \\
\hline \multirow{2}{*}{ Total } & 63 & 78 & 77 & 94 & 312 \\
\hline & $20.2 \%$ & $25.0 \%$ & $24.7 \%$ & $30.1 \%$ & $100.0 \%$ \\
\hline
\end{tabular}

\subsection{Causes of School Violence}

In order to establish the causes of violence in public secondary schools in Nairobi, respondents were asked to state what in their opinion the causes of school violence were. The responses by category of schools were cross tabulated and the results shown in Table 5.

Table 5 shows that competition for resources is the most common cause of school violence at $24.6 \%$ followed by political differences at $21.6 \%$, competition for leadership at $18.3 \%$ and ethnic differences at $17.8 \%$. In terms of category of schools, mixed day public secondary schools presented the highest proportion of incidences of violence. Whereas competition for resources is the most common cause of violence in boys' boarding schools, political differences are the most common cause of violence in girls' boarding and mixed day public secondary schools. Interestingly, gender discrimination ranks a distant fifth and is only more pronounced in CD schools at $4.6 \%$ followed by girls' boarding schools at $3.8 \%$. Girls uniquely appear to have encountered more violence occasioned by gender discrimination.

From the FGD discussions it was clarified that the gender discrimination in girls' boarding schools was attributed to male teachers and to some extent strangers. Such incidences as described above indicate lack of mutual respect 
Table 5. Distribution of the most common form of violence by category of schools.

\begin{tabular}{|c|c|c|c|c|c|c|c|c|}
\hline \multirow[b]{2}{*}{$\begin{array}{l}\text { Most common cause } \\
\text { of violence }\end{array}$} & \multicolumn{7}{|c|}{ Category of School } & \multirow[b]{2}{*}{ Total } \\
\hline & $\begin{array}{l}\text { Boys } \\
\text { Boarding }\end{array}$ & $\begin{array}{l}\text { Girls } \\
\text { Boarding }\end{array}$ & $\begin{array}{l}\text { Boys } \\
\text { Day }\end{array}$ & $\begin{array}{l}\text { Girls } \\
\text { Day }\end{array}$ & $\begin{array}{l}\text { Mixed } \\
\text { Day }\end{array}$ & $\begin{array}{l}\text { Mixed } \\
\text { Day \& } \\
\text { Boarding }\end{array}$ & $\begin{array}{l}\text { Boys } \\
\text { Boarding/Day }\end{array}$ & \\
\hline \multirow{2}{*}{$\begin{array}{l}\text { Gender } \\
\text { Discrimination }\end{array}$} & 6 & 15 & 6 & 0 & 18 & 1 & 0 & 46 \\
\hline & $1.5 \%$ & $3.8 \%$ & $1.5 \%$ & $0.0 \%$ & $4.6 \%$ & $0.3 \%$ & $0.0 \%$ & $11.7 \%$ \\
\hline \multirow{2}{*}{$\begin{array}{l}\text { Competition for } \\
\text { leadership roles }\end{array}$} & 18 & 14 & 12 & 2 & 17 & 4 & 5 & 72 \\
\hline & $4.6 \%$ & $3.6 \%$ & $3.0 \%$ & $0.5 \%$ & $4.3 \%$ & $1.0 \%$ & $1.3 \%$ & $18.3 \%$ \\
\hline \multirow{2}{*}{$\begin{array}{l}\text { Competition } \\
\text { for school/societal } \\
\text { resources }\end{array}$} & 32 & 17 & 17 & 7 & 20 & 1 & 3 & 97 \\
\hline & $8.1 \%$ & $4.3 \%$ & $4.3 \%$ & $1.8 \%$ & $5.1 \%$ & $0.3 \%$ & $.8 \%$ & $24.6 \%$ \\
\hline \multirow{2}{*}{$\begin{array}{l}\text { Ethnic/Tribal } \\
\text { differences }\end{array}$} & 15 & 13 & 13 & 5 & 16 & 4 & 4 & 70 \\
\hline & $3.8 \%$ & $3.3 \%$ & $3.3 \%$ & $1.3 \%$ & $4.1 \%$ & $1.0 \%$ & $1.0 \%$ & $17.8 \%$ \\
\hline \multirow{2}{*}{$\begin{array}{l}\text { Political } \\
\text { differences }\end{array}$} & 17 & 19 & 12 & 7 & 28 & 1 & 1 & 85 \\
\hline & $4.3 \%$ & $4.8 \%$ & $3.0 \%$ & $1.8 \%$ & $7.1 \%$ & $0.3 \%$ & $0.3 \%$ & $21.6 \%$ \\
\hline \multirow{2}{*}{$\begin{array}{l}\text { Competition } \\
\text { for personal } \\
\text { attention/self esteem }\end{array}$} & 5 & 6 & 4 & 0 & 3 & 1 & 5 & 24 \\
\hline & $1.3 \%$ & $1.5 \%$ & $1.0 \%$ & $0.0 \%$ & $0.8 \%$ & $0.3 \%$ & $1.3 \%$ & $6.1 \%$ \\
\hline \multirow{2}{*}{ Total } & 93 & 84 & 64 & 21 & 102 & 12 & 18 & 394 \\
\hline & $23.6 \%$ & $21.3 \%$ & $16.2 \%$ & $5.3 \%$ & $25.9 \%$ & $3.0 \%$ & $4.6 \%$ & $100.0 \%$ \\
\hline
\end{tabular}

among students, a situation which triggers violence. There is need to inculcate respect among the learners through the use of transformative pedagogy. Teachers should engage learners in activities which promote respect for one another. Respect recognizes human dignity. It involves showing regard and appreciating others for who they are in spite of whatever differences which may be in age, political or religious beliefs. The form fours should be encouraged to respect the form ones even though they may be younger.

It is therefore expected that when students learn to respect one another's' opinion within their discussion groups they are bound to practice tolerance in their daily lives. Teaching and learning activities which provide an opportunity for leaners to freely interact and share their diverse views should be encouraged in schools. They are bound to get to know and understand each another much better and the process learn to resolve conflicts amicably therefore coexistence peacefully.

\section{Summary of Results/Findings}

As summarized in the paper, the study established the following four findings:

First, it was established that save for intensity which is higher in Co-educational day schools in the form of mainly fights prominently among boys and verbal abuses among girls, violence is prevalent in all categories of schools.

Secondly, violence mostly takes place during social events such as sports and 
games which took place outside the school compound during which there existed limited or no presence of school authorities.

Thirdly, it was established that the most common perpetrators of violence are classmates especially in Coeducational day schools usually facilitated by the socio environmental risks associated with travelling to and from school by students.

Finally, competition for resources is the most common cause of school violence, followed by political differences, competition for leadership and ethnic differences especially with mixed day public secondary schools presenting the highest proportion of incidences of violence.

\section{Conclusions}

The paper has concluded that the prevalence of violence has been responsible for unrests in public secondary schools in Nairobi County. The prevalence level of violence in public secondary schools in Nairobi County is high among male students, who appeared to be the main perpetrators in different three scenarios. First, it emerged that school violence is prevalent in public secondary school in various forms and manifestations including fighting verbal abuse, bullying, in that order. Although violence cuts across gender in almost equal proportions, it is more prevalent in mixed day schools followed by boys boarding and girls boarding. Secondly, it was also established that competition for resources is the most common cause of violence. Whereas competition for resources is the most common cause of violence in Boys boarding schools, political differences are the most common cause of violence in Girls Boarding and Coeducational day secondary schools.

Thirdly, it emerged that the most common perpetrators of violence are classmates, usually older than the victim and in many instances prefects or fellow students who hold leadership positions in co-curriculum activities. It is also most prevalent during social events followed during meals and on the way home from school all manifesting competition for resources or recognition/awards resources implying that secondary school students have not internalized peace values.

As mitigation measures for the prevalence of violence in secondary schools, the paper has made three recommendations, namely: the establishment of boarding schools as opposed to day schools so as to remove the risks of violence on the way from school so as to manage violence occurring on the way from school and address socio-political and environmental influences arising from families and neighborhoods, which some students carry with them to school; need for equitable distribution of resources to ensure that students do not fight or abuse one another to access the resources; and finally, need for more entrenched teaching of peace education in secondary schools. Presently the curriculum is only largely present in History and Government subject which is an optional subject. Kenya Institute of Curriculum Education (KICD) which is the in- 
stitution mandated to develop curriculum for schools in Kenya should consider integrating peace content in all subjects especially the compulsory subjects so as to enable all students to interact with peace values.

\section{Conflicts of Interest}

The authors declare no conflicts of interest regarding the publication of this paper.

\section{References}

[1] Mc Evoy, C. and Hideg, G. (2017) Time to Decide Global Violent Deaths 2017. A publication of the Small Arms Survey with Support from the Swiss Agency for Development and Cooperation.

[2] UNESCO (2015) Education 2030. World Education Forum 2015, 51.

[3] Eaton, D.K., Laura Kann, S.K., James Ross, M., MA, J.H., William, A., Harris, M., Richard Lowry, M., Wechsler, H., et al. (2016) Youth Risk Behavior Surveillance. MMWR Surveillance Summaries. https://doi.org/10.1016/j.fas.2009.12.004

[4] Souverein, F.A., Ward, C.L., Visser, I. and Burton, P. (2015) Serious, Violent Young Offenders in South Africa: Are They Life-Course Persistent Offenders? Journal of Interpersonal Violence, 31, 1859-1882. https://doi.org/10.1177/0886260515570748

[5] Kanjee, A. and Sayed, Y. (2013) Assessment Policy in Post-Apartheid South Africa: Challenges for Improving Education Quality and Learning. Assessment in Education: Principles, Policy and Practice, 20, 442-469. https://doi.org/10.1080/0969594X.2013.838541

[6] UNESCO-IBE (2010) World Data on Education. 7th Edition, UNESCO, Paris.

[7] Kirioba, T. (2012) The Secondary School Social Environment and Student Violence in Kenya. Elixir International Journal, 46, 8100-8104.

[8] Abobo, F. and Orodho, J.A. (2014) Life Skills Education in Kenya: An Assessment of the Level of Preparedness of Teachers and School Managers in Implementing Life Skills Education in Trans-Nzoia District, Kenya. IOSR Journal of Humanities and Social Science, 19, 32-44. https://doi.org/10.9790/0837-19923244

[9] National Crime Research Center (2016) Rapid Assessment of Arsons in Secondary Schools in Kenya.

[10] Government of Kenya (1991) Report on the Presidential Committee on Student Unrest and Indiscipline in Kenyan Secondary Schools.

[11] Government of Kenya (2001) Report of the Task Force on Student Indiscipline and Unrest (Wangai Report).

[12] Government of Kenya (2008) Report of the Inquiry into Students Unrests and Strikes in Secondary Schools by The Parliamentary Committee on Education, Research and Technology Chaired by Hon David Koech in 2008.

[13] Harber, C. and Sakade, N. (2009) Schooling for Violence and Peace: How Does Peace Education Differ from 'Normal' Schooling ? Journal of Peace Education, 6, 37-41. https://doi.org/10.1080/17400200903086599

[14] Creswell (2014) Research Design. Qualitative, Quantitative, and Mixed Methods Approaches. 4th Edition, Sage Publications, Thousand Oaks, CA.

[15] Krejcie, R.V. and Morgan, D.W. (1970) Determining Sample Size for Research Activities. Educational and Psychological Measurement. Educational and Psychologi- 
cal Measurement, 30, 607-610.

[16] Pickett, W. and Elgar, F.J. (2015) Reducing School Violence in Africa: Learning from Uganda. The Lancet Global Health, 3, e344-e345.

https://doi.org/10.1016/S2214-109X(15)00031-5

[17] Ndetei, D.M., Ongecha, F.A., Khasakhala, L., Syanda, J., Mutiso, V., Othieno, C.J., Kokonya, D.A., et al. (2007) Bullying in Public Secondary Schools in Nairobi, Kenya. Journal of Child and Adolescent Mental Health, 19, 45-55. https://doi.org/10.2989/17280580709486634

[18] Njeri, N.A. and Ngesu, L. (2014) Causes and Effects of Drug and Substance Abuse among Secondary School Students in Dagoretti Division, Nairobi West. Global Journal of Interdisciplinary Social Sciences, 3, 1-4.

[19] Kiprop, C.J. (2012) Approaches to Management of Discipline in Secondary Schools in Kenya. International Journal of Research in Management, 2, 120-139. https://doi.org/10.1016/j.ultsonch.2015.11.014

[20] UNICEF (2015) Prohibiting and Eliminating Corporal Punishment: A Key Health Issue in Addressing Violence against Children. 1-11.

[21] Likoye, M. (2014) Kenyatta University. https://doi.org/10.1097/ACM.0000000000001668 